\title{
The Impact of Terms of Trade Changes on Economic Welfare: Evidence from China*
}

\author{
Jinghua Han, Zhihui Zhang \\ School of International Economics and Trade, Beijing International Studies University, Beijing, China \\ Email: hanjinghua@bisu.edu.cn,zzh_snow@126.com
}

Received May 24, 2012; revised June 5, 2012; accepted July 5, 2012

\begin{abstract}
Based on the statistics of 1993-2010, this paper analyzes the changing trend and causes of terms of trade in China and studies the overall movement in China's national wealth by introducing the GDI index under SNA accounting framework. This paper analyzes the relevance between export and real GDP by using the Pearson correlation and partial correlation method, with the final consumption as the economic welfare evaluation index. This paper also presents the change of national wealth by using the weak axiom of revealed preference theory. The result of the study shows that, China's economic growth is not strongly dependent on exports. It is the export structure of labor intensive products with low price elasticity that mainly lead to the continuously decline of terms of trade in China. However the loss of welfare from the terms of trade's decline is not enough to offset the benefits of the economic growth. Therefore there is no probability of "Immiserizing Growth" in China's foreign trade.
\end{abstract}

Keywords: Terms of Trade; Immiserizing Growth; Economic Welfare

\section{Introduction}

China has benefited a lot from the economy globalization with the international trade as an important promoting tool. According to the data from the custom, China's total import and export volume has been added up to US \$2.97 trillion in 2010 and it is expected to surpass the United States as the number one. Foreign trading is playing a more and more important role in promoting China's economic development. From Adam Smith's absolute cost theory, to David Ricardo's comparative cost theory and to Krugman's new trade theories, it has always been held that the international trade is a giant engine of economic growth. But in the 1960s, some economists proposed an "immiserizing growth" theory, with Bhagwati from India as a representative. In some circumstance, economic growth could result in a country being worse off than before the growth through the international trade. As a developing country and a big trading nation as well, China should try to avoid facing the "immiserizing growth" dilemma when transforming from a big trading nation to a strong one.

Many scholars at home and abroad have done many researches in terms of trade and related issues. Prebisch (1949) deems that the terms of trade of export products

*Fund Project: Supported by "Humanities and Social Sciences Fund of Ministry of Education" (10YJA790063) and "National Statistical Research Fund" (2010LB08). (primary products) in developing countries are deteriorating in the long run. Singer (1950) also draws the same conclusion, which is so-called "Prebisch-Singer hypothesis". Bhagwati (1958) proposes the "immiserizing growth" theory based on the "Prebisch-Singer hypothesis", pointing out that developing countries economic growth lay particular stress on export, and the increase in production and gains may be offset by the worsening terms of trade, leading to absolute decline of domestic residents' income standard and actual consumption standard [1]. Krugman (1989) argues that rapid developing country does not necessarily experience a deteriorating terms of trade process, and they can avoid the drop of relative prices through commodity diversification [2]. Studies conducted by Kehoe \& Ruhl (2008) show that terms of trade do have an impact on a country's actual income and consumption standard. The improvement of terms of trade has a negative effect on the purchasing power of a country, which may reduce consumption and welfare level [3].

Wang et al. (1998) from China have studies the impacts of entry into WTO on terms of trade, showing that the terms of trade has worsen $1.57 \%$ after entering the WTO [4]. Chen and Guo (1999) argue that it is not proper to oppose developing countries to participate in international trade and take the import substitute policy by "Prebisch-Singer hypothesis". Although developing countries will suffer a loss in international trade, while at the 
same time the international trade can also bring many dynamic interests for developing countries [5]. Xu (2002) and Sui et al. (2003) find that there are three decisive factors of terms of trade, which are the relative preference of the professional products, the residents in two countries with comparative advantages of technology and relative productivity of the professional producers [6,7]. Lin et al. (2007) point out that though trade conditions deteriorate, our country's economy has not experienced "immiserizing growth" so far [8]. Based on the Merchandise trade data of UNCTAD, Zhang Yabin (2010) pointed that the terms of trade in China has deteriorated due to the development of the other new emerging economies. That is to say the terms of trade in China is worsening at the premise of "Fallacy of Composition" [9].

In this paper, the terms of trade in an open economy is combined with the changes in the national income in a dynamic economy based on revealed preference analysis. This paper analysis the impact of the terms of trade on China's economic welfare by the introduction of the gross domestic income GDI and domestic final consumption expenditure as the evaluation of indicators of economic welfare.

\section{The Changing Trend and Causes of Terms of Trade}

The terms of trade is an important tool to analyze whether a country is suffering "immiserizing growth" or not. The terms of trade is defined as the ratio of the average price of export commodities to the import commodities, which is given as follows:

$$
\text { TOT }=\frac{P x}{P m} \times 100
$$

For TOT it means the terms of trade and for $P x$ and $\mathrm{Pm}$ they will be import price index and export price index.

Figure 1 gives the import price index, export price

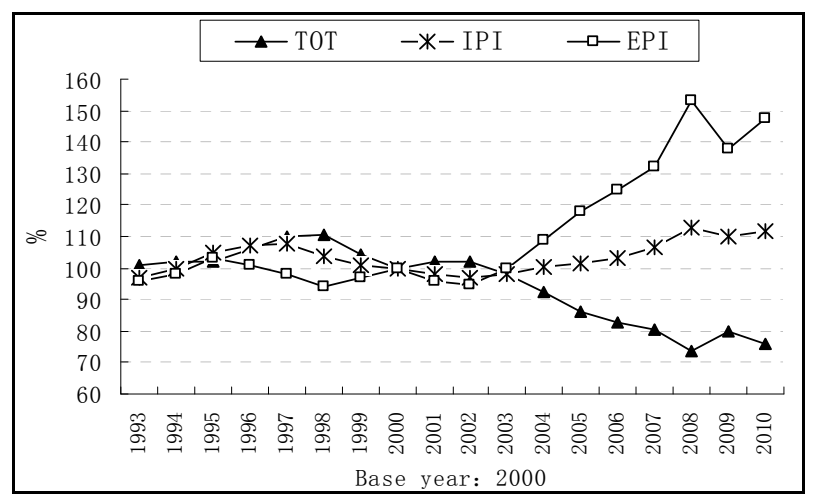

Figure 1. The changing trend of the terms of trade in China in 1993-2010. Sources: Compiled from the World Bank's database. index and the terms of trade (with 2000 as the base year). This paper analyzes the changing trend and causes of terms of trade in three phases:

Phase I (1993-1997): The development direction of structure of export and import in the future in our country was pointed out in this period. The proportion of processing trade rose with fluctuation, the proportion of manufactured goods increased continuously and the proportion of primary products decreased. China mainly exported manufactured goods of which processing trade accounting for a large proportion, and began to import primary products instead, while manufactured goods were still the priority. During this period, the export price index rose steadily, and the import price index rose at first and dropped later. The terms of trade improved continuously.

Phase II (1998-2002): As for the structure of imports and exports, the proportion of processing trade to import declined continuously while to the export remained at a high level of $55 \%$ on average. The proportion of exported primary goods declined and of imported kept rising, but for the manufactured goods, the proportion of exports rose continuously and of imports declined. The proportion of primary goods and manufactured goods to exports and imports developed towards opposite directions. That is to say, there were more and more exported manufactured goods in China, therefore the export price index should go up. However it was not the case. The exports in China depend mainly on processing trade, which was driven by the foreign direct investment (FDI). The growth of FDI in China remained at a rapid speed. After the entry to the WTO since 2001, the trade barriers have reduced and the imports have increased sharply in China. The FDI in exports and imports account for a large proportion in trade in China and the cheap labor forces is the main reason that attracts the FDI. The foreign investors put the end-value products into China to reduce the price of exports. They export the products processed with the imported raw materials and make China the price taker. Therefore, the author holds the idea that the reduce of exported products index, which leads to the declines of terms of trade, is due to the exports of processing products with low price elasticity of demand. Some Chinese scholars think that China experienced the "immiserizing growth" during this period.

Phase III (2003-2010): To analyze the structure of exports and imports in China, we can see the proportion of manufactured goods increased sharply to larger than $93 \%$ on average. The proportion of imports declined continuously with the imports of primary products increasing dramatically and exports decreasing with fluctuation. We may notice that, after the entry to WTO, the growth in exports spurted. Although the amount of exports soured in this period, the price index of exported products rose 
during this period, which indicates that the added value in exported manufactured products was promoted sharply. Because of the increase of skilled workers and the improvement of infrastructure, the mechanical and electrical products and the mechanical equipment products took up a large proportion in the total exports. And this made the condition of foreign trade improve a lot. The growth of exports contributed to the significant increase in China's imported products correspondingly, among which the growth in the imported raw materials was most significant. Also in this period, the world crude oil price and iron ore prices rose sharply, which drove the speedy increase in the import price index. As a result, the increase in import price index was far more than that in export price index and that lead to the downturn in terms of trade. Also in the study, we find that the terms of trade improved for a short term in 2008 due to the shrink of the economy caused by the global financial crisis. During this period, the price of international commodities decreased and the growth bubble in crude oil and iron ore burst. Compared with the export powers such as Japan, Germany and Taiwan province, the export price index dropped slower in China, which indicates that the exports of processing products has not been changed essentially like in Japan and Germany. The exports still relied in the middle- and low-end products with low price elasticity of demand price and the products made in China still regarded as necessities.

\section{Empirical Test of "Immiserizing Growth" Theory in China}

According to Bhagwati, a country should meet the following four prerequisites if it has the "Immiserizing Growth" trend.

\subsection{Economic Growth Depends Strongly on the Export and the Increase in the Export Must Have a Significant Impact on the World Market Price}

The foreign trade in China has increased steadily, with the export accounting for a larger and larger proportion. The proportion of exports to GDP is more than 30\% during the year of 2004-2008. From this point, some Chinese scholar claim that the economic growth in China relies strongly on the exports.

The growth in real GDP in China is pulled by exports $(X)$, consumption ( $C$, final consumer expenditures) and investment ( $K$, gross capital formation) (GDP $=C+K+$ $X-M)$. Therefore when analyzing the relation between the exports and the real GDP, we should control consumption and investment. The author has studies the relationship between exports and real GDP with Pearson relevant and partial correlation analysis method in China in different years and also has the correlation test for consumption, investment and exports. This is shown in Table 1.

Table 1. The result of pearson relevant and partial correlation analysis.

\begin{tabular}{|c|c|c|c|c|c|}
\hline & & real_GDP & real_X & real_C & real_K \\
\hline & Pearson relevance & 1 & $0.982^{* *}$ & $0.997^{* *}$ & $0.995^{* *}$ \\
\hline \multirow[t]{2}{*}{ real_GDP } & Significance (bilateral) & & 0.000 & 0.000 & 0.000 \\
\hline & $\mathrm{N}$ & 21 & 21 & 20 & 21 \\
\hline \multicolumn{6}{|c|}{${ }^{* *}$ significance (bilateral) at 0.01 level. } \\
\hline \multirow{2}{*}{\multicolumn{2}{|c|}{ control variable }} & & \multicolumn{2}{|c|}{ real_GDP } & real_X \\
\hline & & relevance & & & 0.884 \\
\hline \multirow[t]{4}{*}{ real_C real_K } & \multirow[t]{2}{*}{ real_GDP } & significance (bilateral) & & & 0.000 \\
\hline & & $\mathrm{df}$ & & & 16 \\
\hline & \multirow[t]{2}{*}{ control variable } & & \multicolumn{2}{|c|}{ real_GDP } & real_C \\
\hline & & relevance & & & 0.983 \\
\hline \multirow[t]{4}{*}{ real_X real_K } & \multirow[t]{2}{*}{ real_GDP } & significance (bilateral) & & & 0.000 \\
\hline & & $\mathrm{df}$ & & & 16 \\
\hline & \multirow[t]{2}{*}{ control variable } & & \multicolumn{2}{|c|}{ real_GDP } & real_K \\
\hline & & relevance & & & 0.928 \\
\hline \multirow[t]{2}{*}{ real_X real_C } & real_GDP & Significance (bilateral) & & & 0.000 \\
\hline & & df & \multicolumn{2}{|c|}{0} & 16 \\
\hline
\end{tabular}


From the empirical results of Pearson relevant and partial correlation analysis for the real GDP, real export, real consumption and real capital formation in 1990-2010 in China, we find that the correlation coefficient for the real GDP and export is 0.982 , for the real GDP and investment is 0.995 , and for the real GDP and consumption is 0.997 . Although the probability of the correlation coefficient of the three variables is approachable to 0 and they are linear correlation to the GDP (when the level of significance is set as 0.01), we can still find that the real GDP and export is the least correlated, i.e. real export $<$ real investment $<$ real consumption. When we control the investment and consumption, the correlation coefficient of real GDP and real export is 0.884 ; when we control the export and the investment, the correlation coefficient of real GDP and consumption is 0.983; and when we control the export and the consumption, the correlation coefficient of real GDP and investment is 0.928 . Therefore the real GDP and export is still the least correlated, i.e. real export $<$ real investment $<$ real consumption. From the result, we may reach the conclusion that we cannot jump to the conclusion that the economic growth in China relies strongly in the export. Since China has become the world largest exporter, the increase in the demand of export will definitely have a great impact on the world market price.

\subsection{The Demand for the Export Commodities Is Inelastic, and the Increase of Export Supply Will Lead to a Sharp Drop in Price in the International Market}

For it is not easy to get the data of the products quantity and of the change in price, the author has introduced the index instead, i.e. the value index $I V_{t}=\frac{\sum P_{t} Q_{t}}{\sum P_{t-1} Q_{t-1}} \times 100$, the price index $I P_{t}=\frac{\sum P_{t} Q_{t}}{\sum P_{t-1} Q_{t}} \times 100$ and the quantitative index $I Q_{t}=\frac{I V_{t}}{I P_{t}} \times 100$. It is given by:

$$
E_{d t}=\frac{I Q_{t}-100}{I P_{t}-100}=\frac{Q_{x t}-100}{P_{x t}-100}
$$

$E_{d t}$ is for the price elasticity of export, $Q_{x t}$ is for the quantitative index of export and $P_{x t}$ is for the price index of export. We can calculate the price index of export in different months from Jan. 1993 to Sept. 2009 with the formula given by (2), and we can verify whether the export is lack of elasticity by Range (the price elasticity of export, $-1,1)$. According to the result, there are only $12.75 \%$ of the 204 months in which the price of export is lack of elasticity. Therefore we cannot have the conclusion that the demand of import is lack of elasticity, so that the increase of export supply leads to a sharp drop in international market price.

\subsection{It Is a Major Trading Nation, so That the Gain Resulted from the Economic Growth Can Offset the Wealth Loss Brought by the Decline of Terms of Trade}

There is no doubt that China is a major trading nation. Therefore what we should test is whether the change of terms of trade will bring about loss of economic welfare. Although the real GDP is deemed as a measured index of wealth for a country, the author has introduced the concept of GDI (Gross Domestic Income) under the SNA accounting framework to take the terms of trade into consideration $[10,11]$. Thus GDI is given by:

$$
\begin{gathered}
\text { realGDI }=\text { realC }+ \text { realK }+\frac{X-M}{P^{*}} \\
\text { realC }+ \text { realK }=\text { realGDP }-\left(\frac{X}{P_{x}}-\frac{M}{P_{m}}\right),
\end{gathered}
$$

combined with formula (3), we have the following formula:

$$
\text { realGDI }=\text { realGDP }+\frac{X-M}{P^{*}}-\left(\frac{X}{P_{x}}-\frac{M}{P_{m}}\right)
$$

$P^{*}$ is for net exports of goods and services deflator. At the condition of favorable balance of trade, the $P^{*}$ can be replaced by the import price index $P_{M}$ (see $\mathrm{Ke}$ hoe and Ruhl, 2008) [12], considering the different purchasing power for the export of goods and services to buy the import of goods and services at the constant price. So formula (4) can be changed as follows:

$$
\text { realGDI }=\operatorname{realGDP}+\frac{X}{P_{X}}(\text { TOT } / 100-1)
$$

According to formula (3), the author defines the concept of TGR (Trading Gains Rate) as follows:

$$
\mathrm{TGR}=\frac{\text { realGDI }- \text { realGDP }}{\text { realGDP }} \times 100 \%
$$

We take the year of 2000 as the base year in this paper to calculate the TGR of 1993-2010 (see Figure 2). From the figure we may find that the TGR was negative during most years of 1993-2010, which indicates that the real GDI is smaller than real GDP. The TGR has continuously dropped since 1998, showing that the wealth in China suffers a quicken glide. The speed of the wealth loss slowed down after 2008 while we were still in a loss. Though the real wealth suffered from loss because of the decline of the terms of trade, the growth rate in real GDP was much larger than that in TGR. Therefore the wealth loss brought by the decline of terms of trade was not strong enough to 


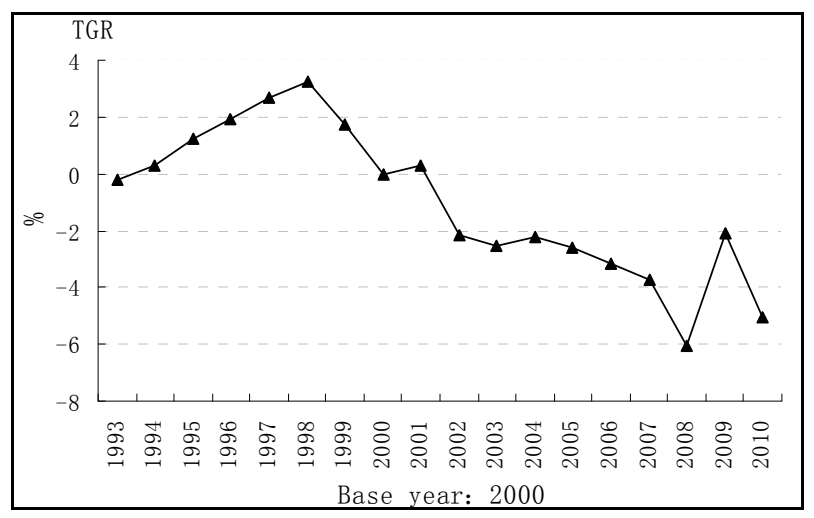

Figure 2. Trading gains rate (TGR). Sources: Compiled from the World Bank's database and China Statistics Yearbook 2010.

offset the gain resulted from the economic growth.

\subsection{The Export Relies Strongly in a Limited Range of Primary Products}

Firstly, the primary products account a small proportion of the export in China and the proportion is dropping year by year from $18.17 \%$ in 1993 to $5.25 \%$ in 2009 . On the contrary, the proportion of manufactured goods increases constantly from $81.83 \%$ in 1993 to $94.75 \%$ in 2009. The exports of high-tech products rise year by year from $17.47 \%$ in 2001 to $31.37 \%$ in 2009 . And an increasing secular trend was observed in processing trade since 2004. This indicates that the proportion of processing trade in China may have a dramatic changed. The processing trade mode of combination of international capital and labor in China may be transferred to other districts, which is very important for the study of whether Chinese economy is experiencing "immiserizing growth". The development mode of trade in China is more like that in Germany and Japan, which is moving forward to the high-tech products with high price elasticity of demand. For a short term, the mid-and-low end products take up a large percentage in exports in China, which is not prominent. The high-tech and mid-and-low end products are well matched in amount. Hence it is very important to study whether there is "immiserizing growth" in economy in China.

To sum up, the results of empirical test has shown that China has partially meet the precondition of "immiserizing growth", while that does not mean that China is experiencing "immiserizing growth" dilemma. More research should be made to analysis the impact on the economic welfare.

\section{Empirical Analysis on the Change of Economic Welfare}

Bhagwati (1958) demonstrated that gains from the eco- nomic growth which lay particular stress on export may be offset by the worsening terms of trade, leading to absolute decline of domestic residents' income level and actual consumption level. We have illustrated the former part with different data and statistics, and we will analyze the later part of the states to check out whether the real income level and consumption level go down. If it is yes, the changes in terms of trade may bring about this result; or we can say that the "immiserizing growth" does not exist in China. This paper use the "terms of trade" instead of "terms of welfare" to state whether a country's economy suffers "immiserizing growth". Weak axiom of revealed preference is a good tool to analysis the impact of the price changing on consumers' welfare [13].

\subsection{Quantitative Index, Revealed Preference and Consumer Welfare}

$b$ is for the base period, the price level is at $\left(p_{1}^{b}, p_{2}^{b}\right)$, and the choice of the consumers is $\left(x_{1}^{b}, x_{2}^{b}\right)$; while at period $t$, the price level is at $\left(p_{1}^{t}, p_{2}^{t}\right)$, and the choice of consumers is $\left(x_{1}^{t}, x_{2}^{t}\right)$.

The Paasche quantitative index and the Laspeyres quantitative index are defined as follows;

$$
V^{\text {Paasche }}=\frac{p_{1}^{t} x_{1}^{t}+p_{2}^{t} x_{2}^{t}}{p_{1}^{t} x_{1}^{b}+p_{2}^{t} x_{2}^{b}}, V^{\text {Lasp }}=\frac{p_{1}^{b} x_{1}^{t}+p_{2}^{b} x_{2}^{t}}{p_{1}^{b} x_{1}^{b}+p_{2}^{b} x_{2}^{b}}
$$

If $V^{\text {Paasche }}>1$, it means the condition is improving at period $t$; if $V^{\text {Paasche }}<1$, we cannot determine which one the consumers prefer, $\left(x_{1}^{t}, x_{2}^{t}\right)$ or $\left(x_{1}^{b}, x_{2}^{b}\right)$. If $V^{\text {Lasp }}<1$, it means the period $b$ is better than period $t$; while if $V^{\text {Lasp }}>1$, we cannot determine which one the consumers prefer, $\left(x_{1}^{t}, x_{2}^{t}\right)$ or $\left(x_{1}^{b}, x_{2}^{b}\right)$.

\subsection{Price Index, Income Index, Revealed Preference and Consumer Welfare}

The definition of Paasche price index, Laspeyres price index and income price index as follows:

$$
\begin{gathered}
P^{\text {Paasche }}=\frac{p_{1}^{t} x_{1}^{t}+p_{2}^{t} x_{2}^{t}}{p_{1}^{b} x_{1}^{t}+p_{2}^{b} x_{2}^{t}}, P^{\text {Lasp }}=\frac{p_{1}^{t} x_{1}^{b}+p_{2}^{t} x_{2}^{b}}{p_{1}^{b} x_{1}^{b}+p_{2}^{b} x_{2}^{b}} \\
M=\frac{p_{1}^{t} x_{1}^{t}+p_{2}^{t} x_{2}^{t}}{p_{1}^{b} x_{1}^{b}+p_{2}^{b} x_{2}^{b}}
\end{gathered}
$$

If $P^{\text {Paasche }}>M$, it means that period $b$ is better than period $t$. When $P^{\text {Lasp }}<M$, it means commodity bundle $\left(x_{1}^{t}, x_{2}^{t}\right)$ is better than $\left(x_{1}^{b}, x_{2}^{b}\right)$, and the consumers' condition is improving at period $t$.

\subsection{Test Criterion of the Weak Axiom of Revealed Preference}

Before the empirical test to the economic welfare in China, we need to definite of the test criterion of the 
weak axiom of revealed preference:

\subsection{Empirical Test of the Changes in Economic Welfare}

Under the SNA accounting framework, the GDP in terms of domestic expenditure is made up of final consumer expenditures $(C)$, total capital formation $(K)$ and net export of goods and services $(X-M)$, which is given by $\mathrm{GDP}=C+K+(X-M)$. Sawada (2003) chose final consumer expenditures $(C)$ as the index for economic welfare and analyzed the changing direction of economic welfare with revealed preference theory [14]. Also he introduced the concept of inner product. So it is in this paper. $p_{C}^{t} \cdot q_{C}^{t}$ is for final consumer expenditures $(C)$, $p_{K}^{t} \cdot q_{K}^{t}$ is for total capital formation $(K)$ and $p_{X}^{t} \cdot q_{X}^{t}$ and $p_{M}^{t} \cdot q_{M}^{t}$ are for the Euclid spaces of import and export price index. i.e.

$$
\begin{gathered}
\mathrm{GDP}^{t}=p_{C}^{t} \cdot q_{C}^{t}+p_{K}^{t} \cdot q_{K}^{t}+p_{X}^{t} \cdot q_{X}^{t}-p_{M}^{t} \cdot q_{M}^{t} \\
\mathrm{GDP}^{b}=p_{C}^{b} \cdot q_{C}^{b}+p_{K}^{b} \cdot q_{K}^{b}+p_{X}^{b} \cdot q_{X}^{b}-p_{M}^{b} \cdot q_{M}^{b} \\
\operatorname{realGDP}=p_{C}^{b} \cdot q_{C}^{t}+p_{K}^{b} \cdot q_{K}^{t}+p_{X}^{b} \cdot q_{X}^{t}-p_{M}^{b} \cdot q_{M}^{t} \\
V_{\mathrm{GDP}}^{\mathrm{Lasp}}=\frac{\mathrm{realGDP}^{t}}{\mathrm{GDP}^{b}}
\end{gathered}
$$$$
V_{C}^{\text {Paasche }}=\frac{p_{c}^{t} \cdot q_{c}^{t}}{p_{c}^{t} \cdot q_{c}^{b}}, \quad P_{C}^{\text {Paasche }}=\frac{p_{c}^{t} \cdot q_{c}^{t}}{p_{c}^{b} \cdot q_{c}^{t}} \text { respectively indi- }
$$

cate the Paasche quantitative index and price index of the finial consumption expenditure; $V_{C}^{\text {Lasp }}=\frac{p_{c}^{b} \cdot q_{c}^{t}}{p_{c}^{b} \cdot q_{c}^{b}}$,

$P_{C}^{\text {Lasp }}=\frac{p_{c}^{t} \cdot q_{c}^{b}}{p_{c}^{b} \cdot q_{c}^{b}}$ respectively indicate the Laspeyres quantitative index and price index of the finial consumption expenditure; $M_{C}=\frac{p_{c}^{t} \cdot q_{c}^{t}}{p_{c}^{b} \cdot q_{c}^{b}}$ is for income index. So formula (9) can be change as:

$$
p_{C}^{b} \cdot q_{C}^{t}=V_{\mathrm{GDP}}^{\mathrm{Lasp}} \cdot \mathrm{GDP}^{b}-\frac{p_{K}^{t} \cdot q_{K}^{t}}{P_{K}^{\text {Paasche }}}-\frac{p_{X}^{t} \cdot q_{X}^{t}}{P_{X}^{\text {Paasche }}}+\frac{p_{M}^{t} \cdot q_{M}^{t}}{P_{M}^{\text {Paasche }}}
$$

In formula (11), $P_{K}^{\text {Paasche }}$ is for the Paasche price index of capital formation, which can be deemed as fixed investments price index. $P_{X}^{\text {Paasche }}$ and $P_{M}^{\text {Paasche }}$ refer to Paasche price index of import and export of goods and service, which can be deemed as the exported and imported goods and service. $P_{C}^{\text {Lasp }}$ is for the social consumption price index, which can be assumed as $P_{C}^{\text {Lasp }}=C P I_{t}$.

We assume last year as the base year $b$ (last year $=100)$ According to the formula listed above about $V_{C}^{\text {Paasche }}$, $P_{C}^{\text {Paasche }}, V_{C}^{\text {Lasp }}, P_{C}^{\text {Lasp }}$ and $M_{C}$, we have the following results.

\subsection{Analysis of the Results}

The result of empirical test by the price index shows that the welfare in China was improving constantly from the year 1993 to 2009 . While the result of variables test show that it cannot clarify whether the welfare in China was improving, but one thing for sure was that the welfare was not worsening. Therefore the economy in China is not experiencing "Immiserizing Growth". Although the conclusion is drawn from the economic perspective, it can still illustrate that the level of real income and consumption in China is not absolute decreasing. The result indicates that the economy growth in China does not meet the precondition of "Immiserizing Growth", which rules out the possibility of immiserizing growth in China.

\section{Conclusions}

This paper has reached the following conclusion:

1) The processing trade has taken up a percentage of more than $50 \%$ in total export since 1998. The export commodities are mainly products with low technology and low value added. The export structure which mainly relies on the labor intensive products is the main reason that leads to the decline of the terms of trade.

2) Test results indicate that the economy in China is stimulated by investments, consumption and exports, which does not rely strongly in the exports. The economic development system should be speeded up to drive the economy by consumption, investments and exports.

3) The trade yield rate in China was negative for most part of 1993-2010, that is to say the GDI is smaller than the real GDP. Since the year of 1998, the trade yield rate has been declining continuously and the loss of wealth

Table 2. Test criterion of the weak axiom of revealed preference.

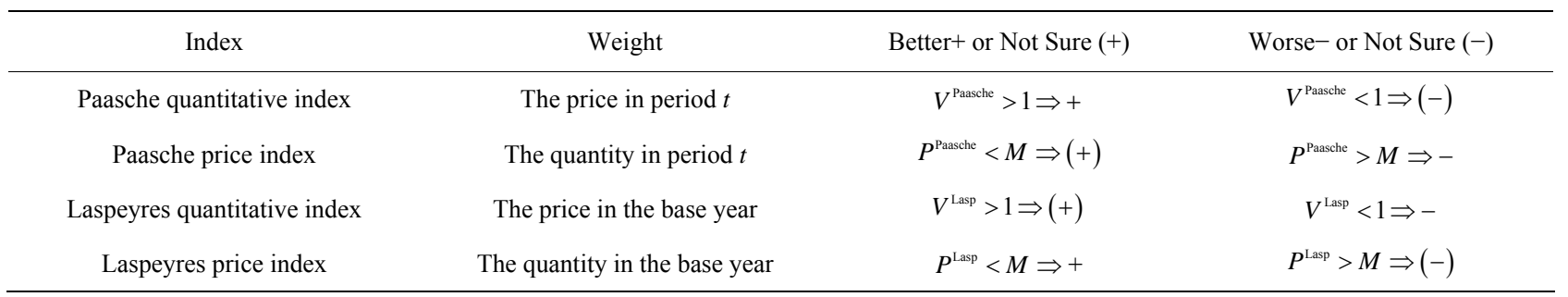


Table 3. Test result.

\begin{tabular}{|c|c|c|c|c|c|}
\hline Year & $V_{c}^{\text {Paasche }}$ & $P_{C}^{\text {Paasche }}$ & $V_{C}^{\text {Lasp }}$ & $P_{C}^{\text {Lasp }}$ & Test Result \\
\hline 1993-1994 & $1.08>1+$ & $1.28<1.34\left(M_{C}\right)(+)$ & $1.04>1(+)$ & $1.24<1.34\left(M_{C}\right)+$ & + or $(+)$ \\
\hline 1994-1995 & $1.07>1+$ & $1.20<1.26\left(M_{C}\right)(+)$ & $1.05>1(+)$ & $1.17<1.26\left(M_{C}\right)+$ & + or $(+)$ \\
\hline $1995-1996$ & $1.10>1+$ & $1.08<1.20\left(M_{C}\right)(+)$ & $1.11>1(+)$ & $1.08<1.20\left(M_{C}\right)+$ & + or $(+)$ \\
\hline 1996-1997 & $1.07>1+$ & $1.01<1.10\left(M_{C}\right)(+)$ & $1.09>1(+)$ & $1.03<1.10\left(M_{C}\right)+$ & $+\operatorname{or}(+)$ \\
\hline $1997-1998$ & $1.08>1+$ & $0.99<1.07\left(M_{C}\right)(+)$ & $1.09>1(+)$ & $0.99<1.07\left(M_{C}\right)+$ & + or $(+)$ \\
\hline 1998-1999 & $1.09>1+$ & $0.99<1.08\left(M_{C}\right)(+)$ & $1.09>1(+)$ & $0.99<1.08\left(M_{C}\right)+$ & + or $(+)$ \\
\hline $1999-2000$ & $1.10>1+$ & $1.02<1.11\left(M_{C}\right)(+)$ & $1.08>1(+)$ & $1.00<1.11\left(M_{C}\right)+$ & + or $(+)$ \\
\hline $2000-2001$ & $1.08>1+$ & $1.04<1.09\left(M_{C}\right)(+)$ & $1.05>1(+)$ & $1.01<1.09\left(M_{C}\right)+$ & + or $(+)$ \\
\hline 2001-2002 & $1.08>1+$ & $1.04<1.07\left(M_{C}\right)(+)$ & $1.03>1(+)$ & $0.99<1.07\left(M_{C}\right)+$ & + or $(+)$ \\
\hline $2002-2003$ & $1.07>1+$ & $1.07<1.08\left(M_{C}\right)(+)$ & $1.01>1(+)$ & $1.01<1.08\left(M_{C}\right)+$ & + or $(+)$ \\
\hline $2003-2004$ & $1.08>1+$ & $1.12<1.13\left(M_{C}\right)(+)$ & $1.01>1(+)$ & $1.04<1.13\left(M_{C}\right)+$ & + or $(+)$ \\
\hline $2004-2005$ & $1.11>1+$ & $1.09<1.13\left(M_{C}\right)(+)$ & $1.04>1(+)$ & $1.02<1.13\left(M_{C}\right)+$ & + or $(+)$ \\
\hline $2005-2006$ & $1.12>1+$ & $1.08<1.14\left(M_{C}\right)(+)$ & $1.05>1(+)$ & $1.02<1.14\left(M_{C}\right)+$ & + or $(+)$ \\
\hline $2006-2007$ & $1.11>1+$ & $1.06<1.17\left(M_{C}\right)(+)$ & $1.10>1(+)$ & $1.05<1.17\left(M_{C}\right)+$ & + or $(+)$ \\
\hline $2007-2008$ & $1.09>1+$ & $1.10<1.16\left(M_{C}\right)(+)$ & $1.05>1(+)$ & $1.06<1.16\left(M_{C}\right)+$ & + or $(+)$ \\
\hline 2008-2009 & $1.09>1+$ & $1.00<1.07\left(M_{C}\right)(+)$ & $1.09>1(+)$ & $0.99<1.07\left(M_{C}\right)+$ & + or $(+)$ \\
\hline
\end{tabular}

has been in an accelerated decline while with a slowdown after 2008. Although the real wealth in China losses with the decline of the terms of trade compared with the trade yield rate, the growth rate in real GDP is higher. Therefore the wealth loss brought by the decline of terms of trade cannot be offset the gain resulted from the economic growth.

4) As for the change of economic welfare, this paper has a scientific test through weak axiom of revealed preference. Through the results, we cannot have the conclusion that the economic welfare is improving in China. While we can arrive at the following conclusion: the economic welfare is not deteriorative in China during the year of 1993-2009 and China's foreign trade has not experienced "immiserizing growth" so far.

\section{REFERENCES}

[1] J. N. Bhagwati, "Immiserizing Growth: A Geometrical Note," The Review of Economic Studies, Vol. 25, No. 3, 1958, pp. 201-205. doi:10.2307/2295990

[2] P. Krugman, "Differences in Income Elasticities and Trends in Real Exchange Rates," European Economic Review, Vol. 33, No. 5, 1989, pp. 1031-1046. doi:10.1016/0014-2921(89)90013-5

[3] T. J. Kehoe and K. J. Ruhl, "Are Shocks to the Terms of Trade Shocks to Productivity?" Review of Economic Dynamics, Vol. 11, No. 4, 2008, pp. 804-819. doi:10.1016/j.red.2008.04.001
[4] Z. Wang, H. J. Wang, S. T. Li and F. Zai, "The Impact of China's WTO Entry on the World Labour-Intensive Products Market and US Agricultural Exports: A Recursive Dynamic CGE Analysis," Economic Research Journal, Vol. 32, No. 4, 1997, pp. 54-65.

[5] X. M. Chen and X. B. Guo, "A Comment on Deteriorating Terms of Trade Theory," Teaching and Research, Vol. 34, No. 7, 1999, pp. 52-57.

[6] J. B. Xu and X. S. Yin, "Deterioration in Terms of Trade and Effectiveness of Comparative Advantage Strategies," World Economy, Vol. 25, No. 1, 2002, pp. 31-36.

[7] G. J. Sui, M. H. Shen and X. Y. Luo, "Common Equilibrium Analysis of the Exasperate Terms of Trade and the Choice of Comparative Advantage Strategy of China," Contemporary Finance \& Economics, Vol. 24, No. 8, 2003, pp. 99-101.

[8] G. J. Lin and Y. Q. Zhang, "Deterioration of Terms of Trade and Immiserizing Growth: Evidence from China," Journal of International Trade, Vol. 33, No. 1, 2007, pp. 3-9.

[9] Y. B. Zhang, M. Che and X. Z. Yi, "Fallacy of Composition and China's Commodity Terms of Trade Deterioration," World Economy Study, Vol. 28, No. 8, 2010, pp. 33-38.

[10] M. Silver and K. Maydays, "The Measurement of a Nation's Terms of Trade Effect and Real National Disposable Income within a National Accounting Framework," Journal of the Royal Statistical Society. Series A (Statistics in Society), Vol. 152, No. 1, 1989, pp. 87-107. doi:10.1016/j.jinteco.2003.07.002 
[11] U. Kohli, "Real GDP, Real Domestic Income, and Termsof-Trade Changes," Journal of International Economics, Vol. 62, No. 1, 2004, pp. 83-106.

[12] M. Reinsdorf, "Terms of Trade Effects: Theory and Measurement", BEA Working Paper, US Department of Commerce, Washington DC, 2009.

[13] S. Wong, "Foundations of Paul Samuelson's Revealed
Preference Theory, Revised Edition: A Study by the Method of Rational Reconstruction," Taylor and Francis, Oxford, 2009.

[14] Y. Sawada, "Immiserizing Growth: An Empirical Evaluation," CIRJE Working Paper CIRJE-F-235, University of Tokyo, Tokyo, 2003. 